\title{
Resources on Sexuality and Development
}

\author{
This issue of Development features some recent books and articles on sexuality and development.
}

\section{References}

Agustín, Laura (2007) Sex at the Margins: Migration, labour markets and the rescue industry, London: Zed Books. Bordo, Susan (1993) UnbearableWeight: Feminism, western culture, and the body, Berkeley: University of California Press. Boston Women's Health Collective (2005) Our Bodies, Ourselves: A new edition for a new era, Boston: New England Free Press.

Butler, Judith (1993) Bodies That Matter, London: Routledge.

Campuzano, Giuseppe (2006) 'Reclaiming Travesti Histories', IDS Bulletin 'Sexuality Matters' 37(5) October.

Campuzano, Giuseppe (2007) 'Are Two Genders Enough? The Travesti Museum in Peru', Gender and Development in Brief 18 (January).

Chambers, Clare (2008) Sex, Culture and Justice:The limits of choice, University Park, PA:The Pennsylvania State University Press.

Connell, Reawyn (2005) 'Masculinities', second edition revised, Cambridge: Polity Press.

Cornwall, Andrea, Elizabeth Harrison and Ann Whitehead (2007) Gender Myths and Feminist Fables:, Oxford:.

Cornwall, Andrea and Susie Jolly (2008) Development with a Body: Sexuality, human rights and development, London: Zed Books.

Corrêa, Sonia (2006) 'Realising Sexual Rights', IDS Bulletin 'Sexuality Matters' 37(5) October.

Corrêa, Sonia, Richard Parker and Rosalind Petchesky (2008) Sexuality, Health and Human Rights, London: Routledge.

Diprose, Rosalyn (1994) The Bodies of Women: Ethics, embodiment and sexual difference, London: Routledge.

Eisenstein, Zillah (2007) Sexual Decoys: Gender, race and war, London: Zed Books.

Esplen, Emily (2007) Gender and Sexuality Supporting Resources Collection Bridge Cutting Edge Pack Sussex: Institute of Development Studies January.

Feminist Dialogues (2007) ‘Transforming Democracy Feminist Visions and Strategies', A Report of theThird Feminist Dialogues at the 7th World Social Forum, Nairobi, Kenya, Isis International Manila, Manila.

Gosine, Andil (2004) 'Sex for Pleasure, Rights to Participation and Alternatives to AIDS: Placing sexual minorities and/or dissidents in development', Working Paper No. 228, Institute of Development Studies: Brighton, October.

Haq, Shireen (2006) 'Sex Workers' Struggles in Bangladesh Learning from the Movement', IDS Bulletin 'Sexuality Matters' 37(5) October.

Harcourt, Wendy and Arturo Escobar (eds.) (2005) Women and the Politics of Place, Bloomfield, CT: Kumarian Press.

Ilkkaracan, Pinar and Susie Jolly (2007) Gender and Sexuality Overview Report Bridge Cutting Edge Pack Brighton: Institute of Development Studies January.

Jolly, Susie (2006) 'Not So Strange Bedfellows: Sexuality and international development', Development Women's Rights and Development 49(1) January.

Susie, Jolly (2007) 'Why the Development Industry Should Get Over its Obsession with Bad Sex and to Start to Think About Pleasure', Working Paper 283, Institute of Development Studies: Brighton, May.

Jolly, Susie and Pinar Ilkkaracan (2007) 'Sexuality Gender and Development', In Brief Bridge Cutting Edge Pack on Gender and Sexuality Sussex: IDS.

Kapur, Ratna (2005) Erotic Justice: Law and the new politics of postcolonialism, New Delhi: Permanent Black.

Nabulivou, Noelene (2006) 'Feminisms, Identities, Sexualities: A personal journey', Development 'Women's Rights and Development' 49(1) March.

Petchesky, Rosalind P. (2002) Global Prescriptions. Gender Health and Human Rights, London: Zed Books in association with UNRISD.

Riccutelli, Luciana, Angela Miles and Margaret McFadden (2004) Feminist Politics, Activism and Vision, London: Zed Books.

Roy, Rahul (2001) 'The Eyes are Silent... The Heart Desires to Speak: Exploring masculinities in South Asia', Development 'Violence against Women and the Culture of Masculinity' 44(3) September.

Sassen, Saskia (1998) Globalization and its Discontents, New York:The New Press.

Scarry, Elaine (1985) The Body in Pain. The Making and UnMaking of the World, Oxford: Oxford University Press.

Tamale, Sylvia (2006) 'Eroticism, Sensuality and Women's Secrets among the Baganda', IDS Bulletin 'Sexuality Matters' 37(5) October. 